\title{
Tin Mineralisation in Nigeria: A Review
}

Abimbola C. Ogunyele*, Adedibu S. Akingboye

Department of Earth Sciences, Adekunle Ajasin University, P.M.B. 001 Akungba-Akoko, Ondo State, Nigeria

Corresponding Author's Email: abimbola.ogunyele@aaua.edu.ng

https://doi.org/10.18280/eesrj.050103

Received: 10 February 2018

Accepted: 13 March 2018

Keywords:

Mineral resources, pegmatite belt, tin mineralisation, Younger Granite

\begin{abstract}
Nigeria is endowed with vast but largely untapped solid mineral resources including tin ores (cassiterite and stannite). Tin, which is one of the oldest metals known to man, is invaluable in a wide variety of uses due to its intrinsic properties such as great malleability and ductility, low melting point, softness, corrosion resistance, non-toxicity, anti-friction qualities, and silvery-white appearance. In the present century, the main uses of tin have been in the coating of steel to produce tinplates, production of alloys (solder, bronze and brass), and chemicals. Tin deposits occur in two distinct provinces in Nigeria. The older suite is related to Pan-African pegmatite belt. This $\mathrm{Sn}-\mathrm{Ta}-\mathrm{Nb}$ mineralized pegmatite belt stretches for over $400 \mathrm{~km}$ from southwestern (Ijebu area) to northern Nigeria (through Wamba-Jema'a to Zuru-Gusau areas). The later stage mineralization is hosted by granites of ring complexes of Jurassic age known as Younger Granites. In the Younger Granites, Sn$\mathrm{Nb}-\mathrm{Ta}$ mineralisation is associated with late-stage peraluminous granites both as disseminations and in veins and greisens. This work synthesizes and discusses the available data on tin mineralisation in Nigeria and possible metallogenesis and controls. Recommendations on how to encourage and improve the mining of tin and its associated minerals in Nigeria are also made in this work.
\end{abstract}

\section{INTRODUCTION}

Tin is one of the metals known to mankind since the earliest times [1-2]. It was possibly one of the first metals used by man as an ingredient of bronze (alloy of copper and tin). Bronze objects such as weapons, tools, jewelry etc with $10-14 \%$ tin have been found in excavations of different ancient civilization. A bronze rod found in Egypt has been dated back to 3700 B.C. Tin has also been found in the tombs of ancient Egyptians and was exported to Europe in large quantities from Cornwall, England during the Roman period [1].

Tin has been mined and used in Nigeria as early as the $9^{\text {th }}$ century with exquisite bronze artifacts from three sites in the Igbo-Ukwu area of Anambra State dating back to this period. These artifacts are older than the earliest Benin bronzes, which are dated to the $13^{\text {th }}$ century [2].

Tin is a relatively soft, pliable and ductile metal with a silvery white colour. The Latin word for tin is "stannum". It is a metallic element ( $\mathrm{Sn}$ ) which occurs in group 14 (or IVa) and period 5 of the periodic table. The atomic number and atomic weight of tin are 50 and 118 respectively.

Physical properties of tin include: silvery-white colour, brilliant luster, high ductility and malleability at $100^{\circ} \mathrm{C}$ $\left(212^{\circ} \mathrm{F}\right)$, low tenacity, specific gravity of 7.3 , low melting point of $232^{\circ} \mathrm{C}\left(449^{\circ} \mathrm{F}\right)$, high boiling point of $2,625^{\circ} \mathrm{C}$ $\left(4,757^{\circ} \mathrm{F}\right)$ and allotropy. Some of the chemical properties of tin are non-toxicity, resistance to oxidation and corrosion, and existence in two oxidation states $(+4$ and +2$)$.

The Earth's crust contains averagely $2-3$ ppm Sn. Primary deposits of tin are considered workable if they have a cut-off grade of $0.35 \%$ (or $3500 \mathrm{ppm}$ ) Sn [3]. However, deposits with lesser grade have been mined. This is because economic and market forces as well as availability of necessary technology play important roles in determining the workability of a deposit [4].

Tin finds industrial applications in the production of corrosion-resistant alloys (bronze, brass, solder), tinplates, chemicals, tin foil, pottery, and glass. Although tin is usually a minor constituent in alloys, it is an essential one on account of the way in which its special properties confer improvements to the matrix metal.

Cassiterite $\left(\mathrm{SnO}_{2}\right)$, stannite $\left(\mathrm{Cu}_{2} \mathrm{SnFeS}_{4}\right)$ and cylinderite $\left(\mathrm{Pb}_{3} \mathrm{Sn}_{4} \mathrm{FeSb}_{2} \mathrm{~S}_{14}\right)$ are the major ore minerals of tin. Tin ores occur mainly in veins, stockworks, disseminations, pegmatites, replacements and placers. Primary tin deposits are formed by magmatic, hydrothermal and/or replacement processes. Secondary deposits are the products of weathering of primary deposits, and the subsequent transportation and deposition of the resulting sediments in a new environment.

Tin deposits are abundant in China, Malaysia, Indonesia, Peru, Thailand, Brazil, Bolivia, D.R. Congo, Australia, Nigeria, Myanmar (Burma), Russia, Zimbabwe, Rwanda, South Africa, United Kingdom, Mongolia, Colombia, Germany, Canada, Mexico and Morocco [5-8].

The estimated total world reserve of tin metal as at 2017 is over 4.80 million tonnes and global production amounted to 290,000 tonnes with China being the largest producer (100,000 tonnes) and Nigeria contributing about 2,400 tonnes [9]. About $80 \%$ of tin mined in Nigeria is from secondary deposits found downstream (tin placer deposits) derived from primary tin lodes and granitic rocks [10]. 


\section{OVERVIEW OF THE GEOLOGY AND MINERAL RESOURCES OF NIGERIA}

The geology and mineral resources of Nigeria have been studied in details by several geoscientists [6, 11-17].

Obaje [17] divided the geology of Nigeria into 3 major petrological components - Basement Complex, Younger Granites, and Sedimentary Basins of Precambrian $(\geq \pm 600$ Ma), Jurassic (ca. $150 \mathrm{Ma})$ and Cretaceous - Recent $(\leq 145$ Ma) ages respectively (Figure 1).

Mineral resources associated with the Basement Complex rocks of Nigeria include gold, lead-zinc-copper, iron formation, silver, gemstones, marble, talc, sillimanitekyanite-andalusite, etc. The Younger Granites are notable for their $\mathrm{Sn}-\mathrm{Nb}$-Ta mineralisation and associated minerals such as sphalerite, pyrite, uraninite, thorite, fluorite and pyrochlore [18].

Hydrocarbon deposits (crude oil, natural gas, coal and bitumen) have been found in most sedimentary basins of Nigeria [17, 19-20]. Lead, zinc, copper, silver, uranium, brine, ironstone, baryte, gypsum, limestone, clays, sands and gravels, diatomite are other mineral resources concentrated in the sedimentary basins of Nigeria [21-24].

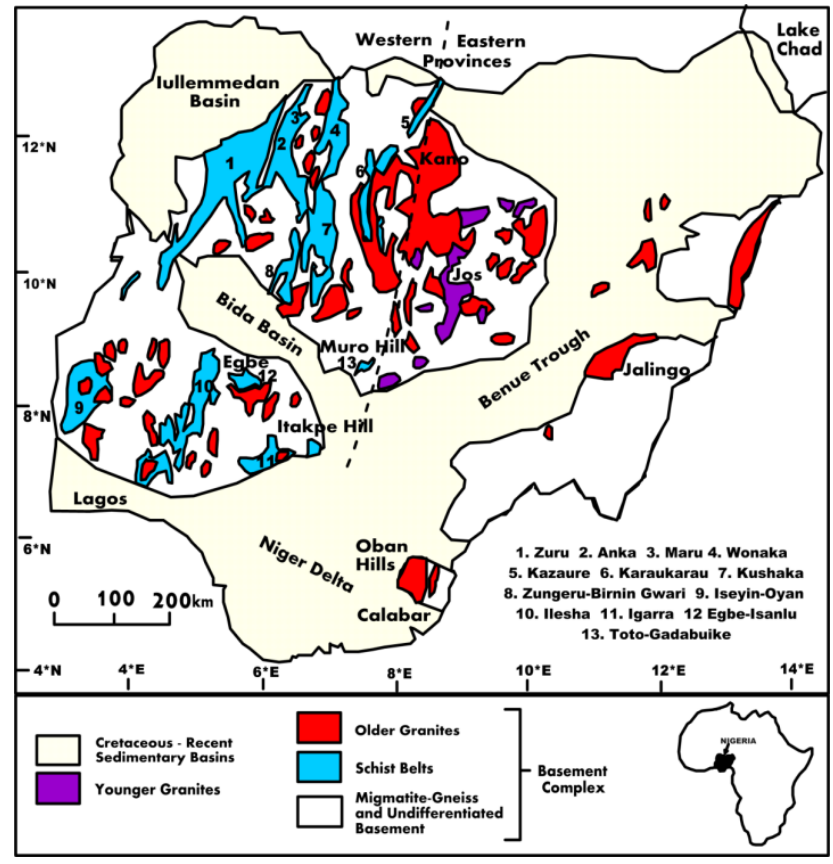

Figure 1. Outline geological map of Nigeria (modified after [15])

\section{TIN MINERALISATION IN NIGERIA}

Tin minerals, particularly cassiterite are one of the mineral endowments of Nigeria [25-26]. There are two tin provinces in Nigeria. These provinces form parts of the four major metallogenic provinces of the country [27].

The four metallogenic provinces of Nigeria (Figure 2) are:

1. Sn-Ta-Nb Pegmatite Belt of Late Pan-African age

2. Sn-Nb-Ta Younger Granite Province of Jurassic age

3. $\mathrm{Pb}-\mathrm{Zn}$ Province of the Benue Trough of Cretaceous age

4. Au Province of Western Nigeria

This paper discusses only the tin metallogenic provinces of Nigeria. [21, 30-31] and other related literatures have extensively researched on the $\mathrm{Pb}-\mathrm{Zn}$ and Au Provinces of the Benue Trough and western Nigeria respectively.

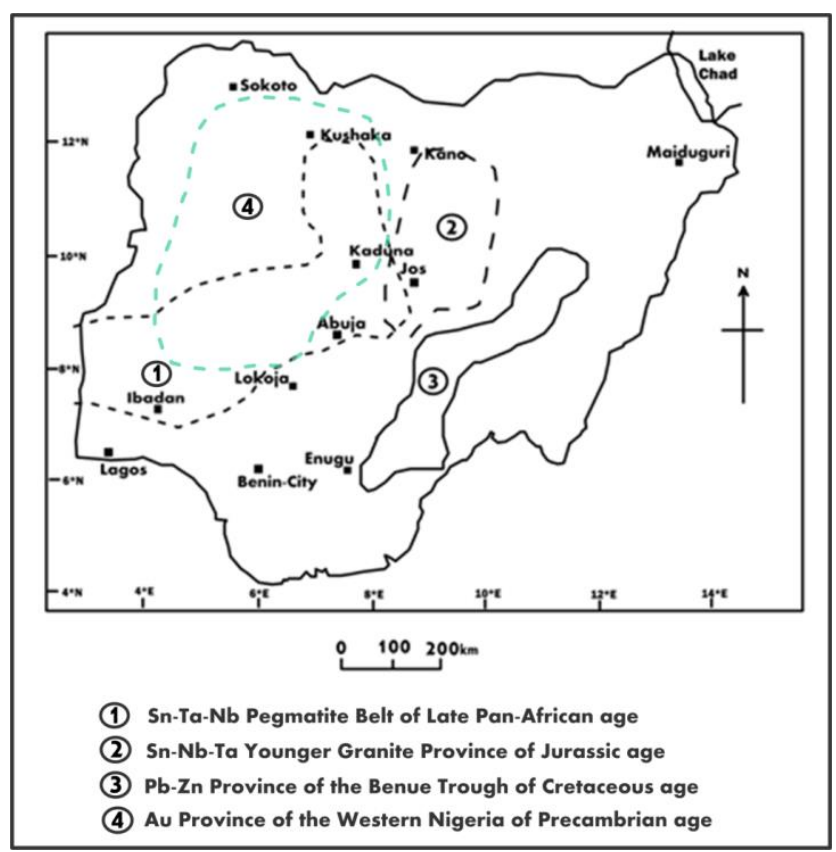

Figure 2. Metallogenic Map of Nigeria (modified after [27-29])

\subsection{Sn-Ta-Nb Pegmatite Belt of Late Pan-African age}

The Sn-Ta-Nb Pegmatite Belt of Nigeria consists of over 3,000 tin-bearing pegmatites of diverse mineralogy, structural orientations and chemical compositions ranging between $10 \mathrm{~m}-1,500 \mathrm{~m}$ in length and sometimes up to $50 \mathrm{~m}$ in width occurring in granites, schists, gneisses, amphibolites and quartzites $[25,29]$. The mineralized pegmatite belt extends from southwestern (Ijebu area) to northern Nigeria (through Wamba-Jema'a to Zuru-Gusau area) covering a broad, over $400 \mathrm{~km}$ long zone trending NE-SW and parallel to the linear pattern of the other two metallogenic provinces (Younger Granite and Cretaceous Benue Trough provinces) $[25,29,32,33]$. The pegmatite belt of Nigeria is presumed to extend into northeast Brazil [28, 34, 35].

The mineralized or rare metal-bearing pegmatites consist mainly of quartz, potash feldspar, albite, muscovite and less commonly, biotite and a range of accessory minerals including tourmaline, beryl, aquamarine, lepidolite and economically important cassiterite, columbite and tantalite.

The mineralized pegmatite belt, also known as the Older Tin field of Nigeria, is the only basement metallogenic feature that cross-cuts the schist belt structures although most pegmatites are oriented N-S $[32,36]$. The belt is divided into 3 zones: (i) the main central Nigerian pegmatite belt (ii) area of richest stanniferous pegmatites (iii) and area of subordinate mineralization (Figure 3 ).

Okunlola [29] grouped the rare-metal bearing pegmatites of Nigeria into seven broad fields, which are: Kabba-Isanlu, Ijero-Aramoko, Ibadan-Oshogbo, Oke-Ogun, NassarawaKeffi, Kushaka-Birnin-Gwari and Lema-Share fields (Figure 4). The tin concentrations of some of the rare metal-bearing pegmatites in these fields are shown in Table 1.

Notable mineralized pegmatites are found in Ijero, Sepeteri, Aramoko, Ife-Ilesha, Ikoro, Osu, Igbeti, Oro, OkeOgun, Komu, Egbe, Akata, Wamba-Jema'a, Keffi, Akwanga, 
Gwon Gwon, and Jos Plateau, all occurring within the Nigerian mineralized pegmatite belt. A few occurrences of poor - low grade tin-bearing pegmatites have also been found outside the pegmatite belt in the Obudu and Oban massifs in southeastern Nigeria [29, 33, 37-40]. The mineralized pegmatites have yielded about $5 \%$ of the total cassiterite produced in Nigeria [25, 41].

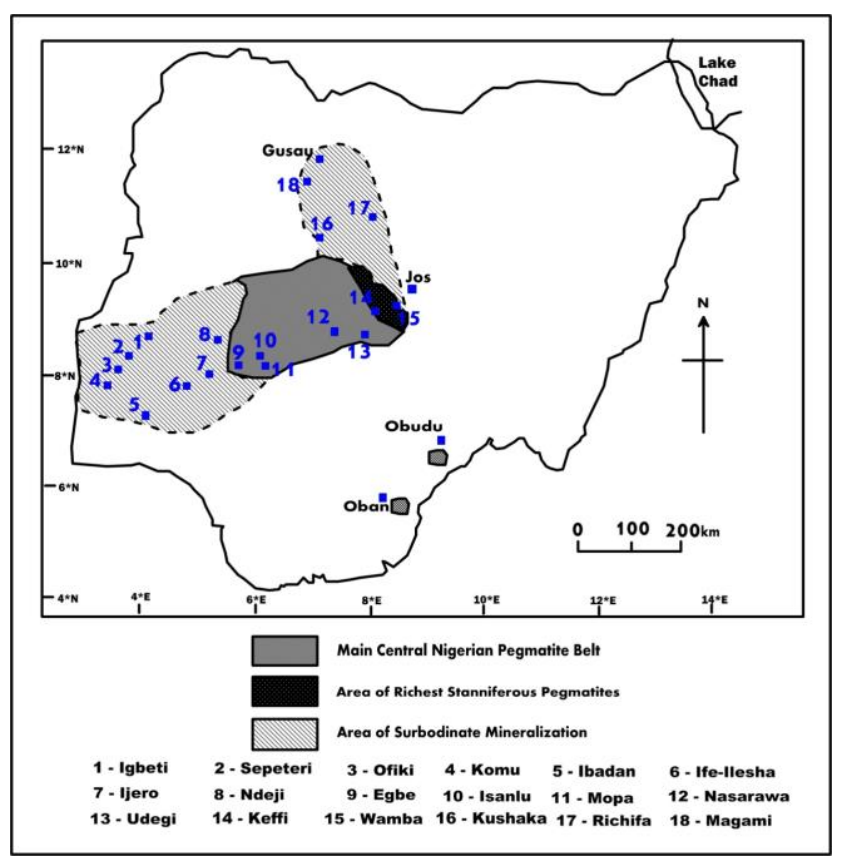

Figure 3. Map showing the locations of notable tin-bearing pegmatites in Nigeria (modified after [28, 29, 36])

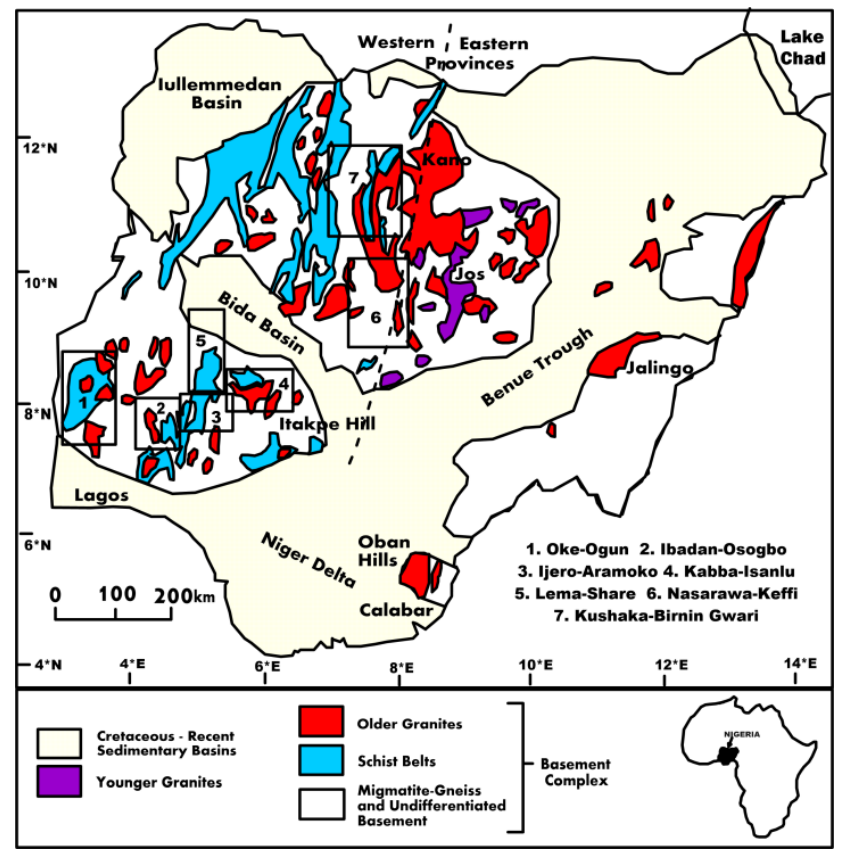

Figure 4. Geological Map showing the Pegmatite Fields of Nigeria (modified after [29])

Notable mineralized pegmatites are found in Ijero, Sepeteri, Aramoko, Ife-Ilesha, Ikoro, Osu, Igbeti, Oro, OkeOgun, Komu, Egbe, Akata, Wamba-Jema'a, Keffi, Akwanga, Gwon Gwon, and Jos Plateau, all occurring within the Nigerian mineralized pegmatite belt. A few occurrences of poor - low grade tin-bearing pegmatites have also been found outside the pegmatite belt in the Obudu and Oban massifs in southeastern Nigeria [29, 33, 37-40]. The mineralized pegmatites have yielded about $5 \%$ of the total cassiterite produced in Nigeria [25, 41].

The Nigerian tin-bearing pegmatites are probably related to the Pan-African Older Granite suite which often occurs in close proximity. The mineralized pegmatites were formed due to magmatic differentiation processes during late PanAfrican orogenic event, in the range 580 - $500 \mathrm{Ma}$ [48, 54]. They are younger than the Older Granites and barren pegmatites but older than the Younger Granites. Tin-bearing pegmatites associated with metasedimentary rocks (schists, paragneisses and quartzites) in schist belts (as in Ijero, Egbe, Ilesha) suggest metamorphic or metasomatic replacement processes (particularly late-stage albitization) are important in their formation $[17,36,55]$.

\subsection{Sn-Nb-Ta Younger Granite Province of Jurassic Age}

The Younger Granite Province in north central Nigeria, trending NE-SW, covers a total area of about $7,500 \mathrm{~km}^{2}$. The province consists of over 50 massifs of anorogenic complexes (Figure 5) made up of both volcanic (rhyolites, trachytes and basalts) and plutonic rocks (aegirine-, arfvedsonite-, riebeckite-, biotite- and hornblende-bearing granites, syenites, quartz porphyry, granite porphyry and gabbro) formed during the Mesozoic, probably related to the early break-up of Gondwanaland and splitting of Africa from South America. This event was also responsible for the opening up of the Benue Trough [56]. The Younger Granite Province terminates the $\mathrm{Sn}-\mathrm{Ta}-\mathrm{Nb}$ Pegmatite belt in the east. Wright [36] referred to the Younger Granite Tin Province as Younger Tin field of Nigeria.

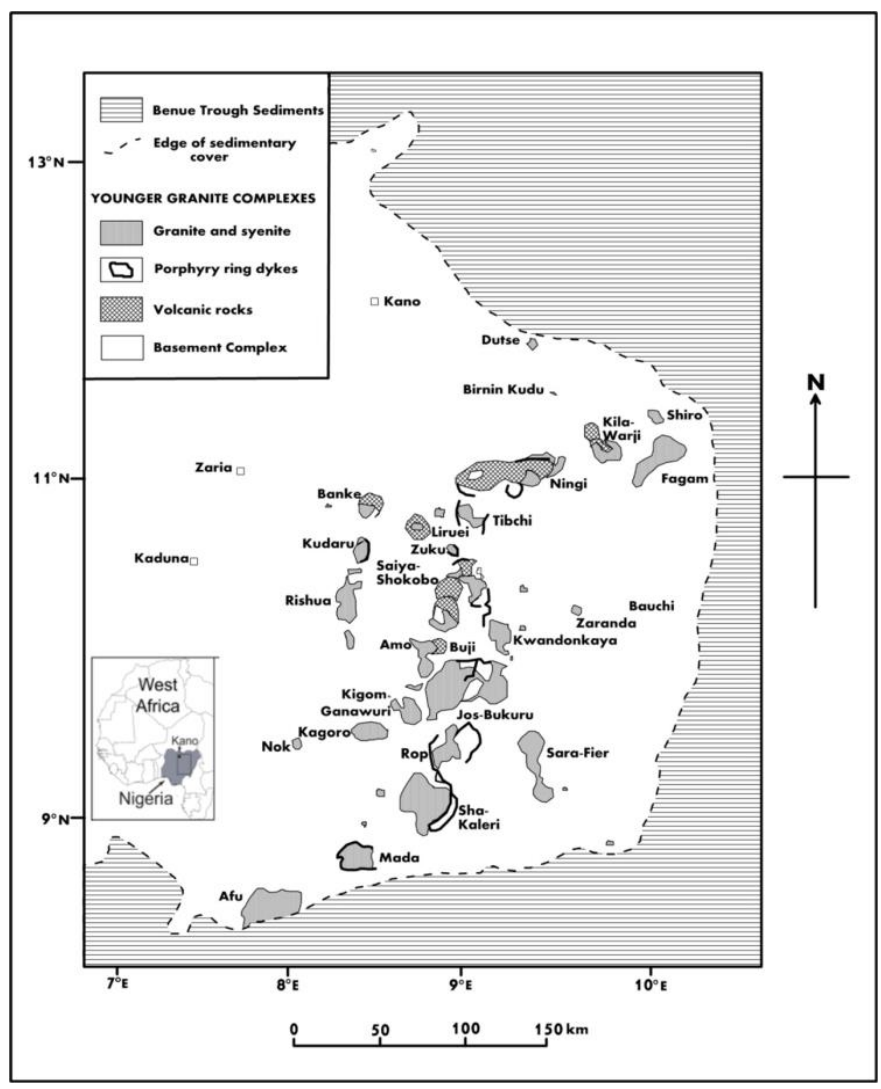

Figure 5. Geological Map of the Sn-Nb-Ta Younger Granite Province of Nigeria [2, 58-59] 
Table 1. Tin ( $\mathrm{Sn}$ ) concentrations of some rare metal-bearing pegmatites of Nigeria

\begin{tabular}{|c|c|c|c|c|}
\hline $\begin{array}{l}\text { Pegmatite } \\
\text { Field }\end{array}$ & Location & Host $\operatorname{Rock}(\mathbf{s})$ & $\begin{array}{l}\text { Average and Range } \\
\text { of Sn content (ppm) }\end{array}$ & References \\
\hline \multirow{2}{*}{$\begin{array}{l}\text { Ijero- } \\
\text { Aramoko }\end{array}$} & Ijero & $\begin{array}{l}\text { Biotite Schist and } \\
\text { Amphibole Schist }\end{array}$ & $18 ; 4-37$ & {$[42]$} \\
\hline & Oke-Asa & $\begin{array}{l}\text { Biotite Schist and } \\
\text { Biotite Gneiss }\end{array}$ & $8.3 ; 5-14$ & [43] \\
\hline \multirow{4}{*}{$\begin{array}{l}\text { Nassarawa- } \\
\text { Keffi }\end{array}$} & $\begin{array}{l}\text { Wamba (Angwan } \\
\text { Rimi) }\end{array}$ & $\begin{array}{l}\text { Biotite Gneiss and } \\
\text { Schist }\end{array}$ & $105 ; 12-137$ & {$[44]$} \\
\hline & Nassarawa & Granite and Schist & $\begin{array}{c}136 ; 9-659(\mathrm{WR}) \\
352 ; 61-902(\mathrm{ME})\end{array}$ & $\begin{array}{l}{[28] ;} \\
{[45]}\end{array}$ \\
\hline & $\begin{array}{c}\text { Keffi } \\
\text { Angwan Mallam } \\
\text { Angwan Doka }\end{array}$ & $\begin{array}{c}\text { Schist } \\
\text { Granodiorite }\end{array}$ & $\begin{array}{l}760 ; 5-6000 \\
638 ; 5-3373\end{array}$ & {$[46]$} \\
\hline & Gwon-Gwon & Granite \& Gneiss & $72.4 ; 66-79$ & [47] \\
\hline \multirow{3}{*}{ Oke-Ogun } & Komu & $\begin{array}{c}\text { Gneiss, Schist and } \\
\text { Amphibolite }\end{array}$ & $242.5 ; 0.05-777$ & [48] \\
\hline & Igbeti & Schist and Gneiss & $18.5 ; 10-25$ & [49] \\
\hline & Sepeteri & Amphibole Schist & $50.41 ; 11.2-279$ & [50] \\
\hline \multirow[t]{2}{*}{ Kabba-Isanlu } & Egbe & $\begin{array}{c}\text { Amphibolite, Gneiss } \\
\text { and Schist }\end{array}$ & 92.3 & [51] \\
\hline & Oro & Schist \& Gneiss & $6.06 ; 1.06-14.89$ & {$[52]$} \\
\hline $\begin{array}{l}\text { Ibadan- } \\
\text { Oshogbo }\end{array}$ & Awo & Banded Gneiss & $\begin{array}{c}109 ; 2-244(\mathrm{WR}) \\
1089.8 ; 1050-1104 \\
\text { (ME) }\end{array}$ & {$[53]$} \\
\hline \multirow{3}{*}{$\begin{array}{l}\text { Kushaka- } \\
\text { Birnin-Gwari }\end{array}$} & Kushaka & $\begin{array}{l}\text { Schist, Gneiss and } \\
\text { Migmatite }\end{array}$ & 148 & [28] \\
\hline & Magami & $\begin{array}{l}\text { Gneiss and } \\
\text { Migmatite }\end{array}$ & 7 (WR), 234 (LME) & [28] \\
\hline & Richifa & Granite & 6 & [28] \\
\hline Lema-Share & Lema-Ndeji-Share & $\begin{array}{l}\text { Gneisses and } \\
\text { Granitoids }\end{array}$ & $85 ; 15-125$ & {$[25]$} \\
\hline
\end{tabular}

WR - Whole Rock Pegmatite, ME - Muscovite Extract, LME - Lithium Muscovite Extract

Tin ores (cassiterite and stannite) occurs in the Younger Granite complexes in two primary forms: (i) disseminations and (ii) veins and greisens. Disseminations of accessory cassiterite occur in association with columbite, tantalite and other ores (monazite, zircon, cryolite, rutile, ilmenite, genthelvite, beryl, molybdenite, sphalerite and chalcopyrite) in the roof zones and margins of peraluminous biotite granites in most of the Younger Granite Complexes, but known enrichment is focused in parts of the Jos-Bukuru, Tongolo, Tibchi, Dutsen-Wai and Afu complexes. The values in a particular granite may vary from zero to over $400 \mathrm{ppm}$ $\mathrm{SnO}_{2}$ (Table 2) [6, 10, 57].

The peralkaline granites, inspite of their high Sn content as revealed by chemical analyses, contain no cassiterite ore. This suggests that $\mathrm{Sn}$ did not occur as cassiterite but probably remains dispersed in the sodic-bearing minerals [6, 10]. However, the peralkaline albite-riebeckite granites contain significantly high concentrations of niobium, zinc, uranium and zirconium [68].

Few highly mineralized quartz-sulphide-cassiterite veins and greisens enriched in cassiterite, stannite, sphalerite, galena, columbite, chalcopyrite, siderite, arsenopyrite, wolframite and bismuth minerals occur within fractures and along the margins of Younger Granite rocks. These are the most economically viable primary tin deposits in the province. Notable cassiterite-bearing veins or lodes and/or greisens occur in the Ririwai, Tibchi, Tongolo and Afu complexes (in decreasing order of mineralisation).
Over $95 \%$ of the tin (cassiterite) produced in Nigeria was mined in the Younger Granite Province and were won from alluvial deposits derived from the tin-bearing granites and lodes $[2,69]$.

The origin of the Sn-Nb-Ta mineralization in the Younger Granite Province is related to the petrogenesis of the Younger Granites. Wright [36] suggested that cassiterite and its associated ore minerals in the Younger Granite ring complexes of Nigeria were not basement-derived, but originated at deeper levels as part of the primary melts. This suggestion was based on the premise that the Younger Granite magmas probably originated in the upper mantle, as salic melts, generated by pressure relief, partial melting, and a concentration of low melting constituents beneath a broad crustal dome, and modified by interaction with basement rocks.

Wright [36] further argued that the ore mineral constituents of the Younger Granites were not extracted and concentrated from the crustal rocks through which the salic magma rose because:

i. There is greater volume of mineralisation in the Younger Granites as compared to the basement, and

ii. Contrasting mineral assemblages associated with the basement tin mineralization and the Younger Granites. Boron, beryllium and tantalum are rare in the Younger Granites but common in the basement pegmatites. Conversely, fluorine, tungsten and hafnium are common in the Younger Granites but rare in the basement. 
Table 2. Tin (Sn) concentrations in some lithologies of the Younger Granite Complexes

\begin{tabular}{|c|c|c|c|}
\hline $\begin{array}{c}\text { Younger Granite } \\
\text { Complex }\end{array}$ & Rock Type & Sn content (ppm) & References \\
\hline \multirow{11}{*}{ Ririwai } & Biotite granite & $28 ; 64$ & [60]; [61] \\
\hline & $\begin{array}{c}\text { Aegirine }- \text { arfvedsonite } \\
\text { granite }\end{array}$ & 24 & {$[61]$} \\
\hline & Albite - arfvedsonite granite & 67 & [61] \\
\hline & Albite - riebeckite granite & 165 & [60] \\
\hline & Potassic granite & 55 & {$[60]$} \\
\hline & Quartz-porphyry & 15 & {$[61]$} \\
\hline & Kaolinised granite & 6 & [60] \\
\hline & Partial greisen & 1500 & {$[62]$} \\
\hline & Greisen assemblage & $2016 ; 1670$ & {$[62] ;[60]$} \\
\hline & Ririwai Zn-Sn lode & $6100-7000$ & [38] \\
\hline & Ginshi Hill Sn lode & $100-21,800^{*}$ & [63] \\
\hline \multirow{2}{*}{ Jos-Bukuru } & Biotite albite granite & $20-1433 *$ & [63] \\
\hline & Biotite granite & 63 & [61] \\
\hline \multirow{2}{*}{ Banke } & Biotite granite & 9 & {$[60]$} \\
\hline & Greisen & 1150 & {$[60]$} \\
\hline \multirow{2}{*}{ Tibchi } & Biotite granite & 90 & [57] \\
\hline & Biotite granite & 47 & [64] \\
\hline \multirow{5}{*}{ Tongolo } & Biotite granite & 55 & [64] \\
\hline & Greisenized granite & 213 & {$[64]$} \\
\hline & Greisen & 494 & [64] \\
\hline & Pakaru Sn-Zn-W lode & 7500 & [64] \\
\hline & Biotite granite & 190 & [57] \\
\hline Dutsen-Wai & Afu biotite granite & 12 & [65] \\
\hline \multirow{7}{*}{ Afu } & Igo biotite granite & 50 & {$[65]$} \\
\hline & Jenta biotite granite & 74 & [65] \\
\hline & Odegi albite biotite granite & 56 & [65] \\
\hline & Kaolinized granite & 180 & [65] \\
\hline & Greisenized granite & 685 & [65] \\
\hline & Greisen & 2160 & {$[65]$} \\
\hline & Arfvedsonite-aegirine granite & 32 & [65] \\
\hline \multirow{4}{*}{ Shere } & Arfvedsonite-biotite granite & 22 & [66] \\
\hline & Biotite granite & 14 & [66] \\
\hline & Albite-arfvedsonite granite & 47 & [66] \\
\hline & Biotite granite & 58 & [67] \\
\hline \multirow{2}{*}{ Kwandonkaya } & Biotite granite & 21 & [67] \\
\hline & Pashanu microgranite & 31 & [67] \\
\hline
\end{tabular}

\section{CONTROLS OF TIN MINERALIZATION IN NIGERIA}

The distribution of stanniferous pegmatites in the Nigerian Basement and the Younger Granite ring complexes can be more plausibly related to a proposed ancient lineament system than to regional structural trends (Figure 6) [25, 36, 70]. These lineaments possibly acted as passage ways for the mineralizing fluids to be transported and also to deposit their mineral contents. Areas close to the intersection of the lineaments, particularly around the Jos Plateau, contain the richest pegmatites and tin-bearing granites and lodes. This may suggest intermediate activeness of these lineaments especially in the Late Precambrian times [25, 71].

Noticeably, tin-bearing pegmatites in the Late Pan-African Terrain of Nigeria are concentrated close to major faults of transcurrent nature, for example, the Kalangai fault system, Ifewara fault system and Anka fault system which has a southern extension up to the Oke-Ogun areas in southwestern Nigeria $[25,28]$. These structures are also of importance in the localization and structural controls of tin mineralization in Nigeria particularly in the pegmatite belt.

The proximity of most of the rare-metal bearing pegmatite fields to major transcrustal suture zones and subsidiary faults also suggests their timing of emplacement are related to that of gold mineralization [29, 72].

\section{TIN RESERVE OF NIGERIA}

As at 2010, the estimated tin (cassiterite) reserve of Nigeria is at least 300,000 tonnes [73]. In addition to the estimated reserve, a substantial unestimated amount of cassiterite is known to be buried under basalts and volcanics in the Jos Plateau area [69, 74-75]. Tin resource of Nigeria is estimated to be at least double the amount of reserve. The low level of exploration and estimation of most mineral deposits in Nigeria including tin makes unavailable the accurate amount of mineral resources in the country. 


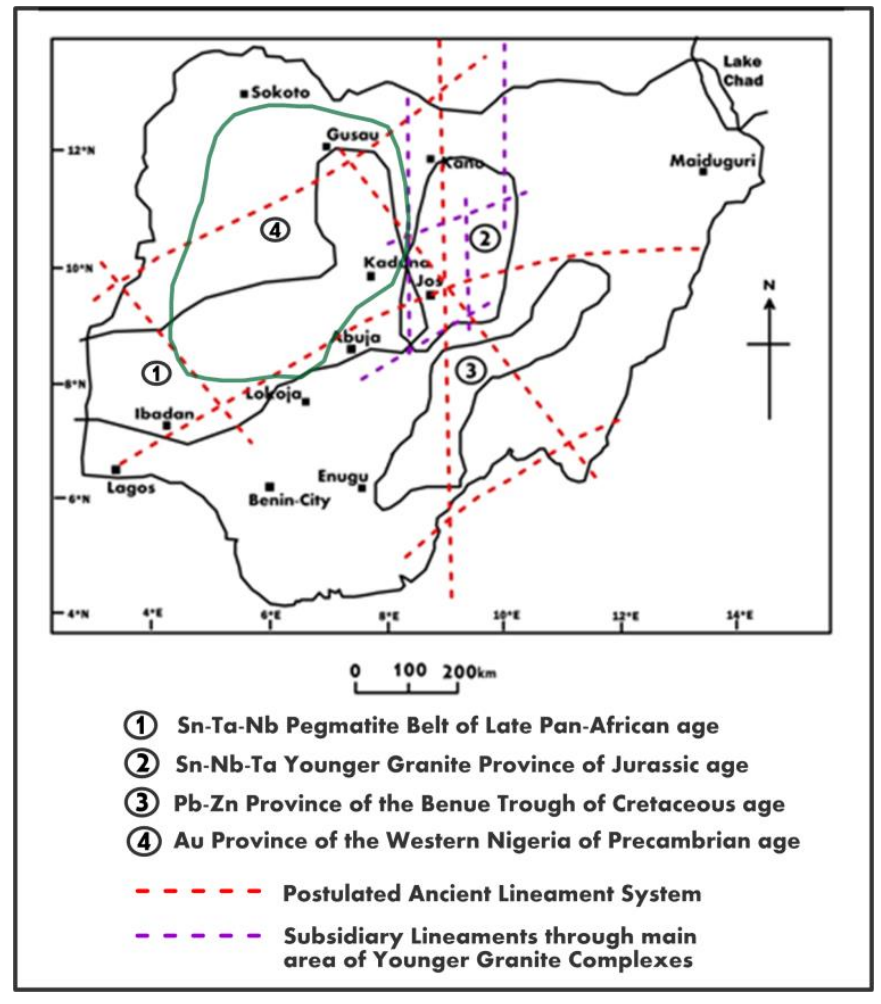

Figure 6. Lineament Map of Nigeria (modified after [36])

\section{DISCUSSION AND RECOMMENDATIONS}

A substantial percentage of the tin deposits in Nigeria, particularly lodes and greisens in the Younger Granite province and the tin-bearing pegmatites are of economic grade and tonnage. However, most of these deposits have not been properly explored, quantified and mined [3].

Overdependence on revenue from oil and gas exports is the major reason for the neglect of this mineral and other solid minerals which have been a major source of income for Nigeria in the past. In fact, Nigeria was the $5^{\text {th }}$ largest producer of tin and the world's leading producer of columbite in 1965 [76]. After that time, production began to decline drastically even up till date. Other factors that have contributed to the neglect of the solid minerals are fall in price, illegal mining and sales, lack of sophisticated modern mining equipment and funds as well as inability to locate fresh deposits in the past.

What is the way forward? How can tin production be revived in Nigeria? Recommendations on how to revive the production of tin as well as other solid minerals include:

1. Acquisition and provision of advanced and sophisticated mining equipment by the government and interested individuals so as to be able to mine the tinbearing lodes and pegmatite fields. The equipment can be rented out to interested miners at affordable prices. This will no doubt encourage mining, provide employment and generate income for the government and private investors.

2. Development of equipment by Nigerians (students, teachers, researchers, engineers, etc) which can be used to mine marginal (low grade) ores so that previously non-minable deposits can be profitably mined [10].

3. Training of young people to become professionals in mineral exploration and exploitation, thereby adding to the technical manpower base of the nation.
4. More detailed exploration to find new (hidden) lodes and pegmatites, buried alluvial and other deposits of economic potential.

5. Prevention of illegal mining by indigenes and mining companies. This can be done by the enactment and enforcement of strict mining laws and fines to prohibit such activities.

6. Easy access to mineral rights and mining licenses as well as guaranteed security of tenure.

7. Provision of mining incentives, loans and tax relief to mining companies.

8. Establishment of local manufacturing companies that use tin in the production of different materials.

9. Good governance, political stability, good resource management and shunning of corrupt practices.

10. Provision of basic social amenities such as security, good transportation system, stable power supply, etc. This will encourage investors, both local and foreign, to invest in mining in Nigeria and assure them of making profits.

\section{CONCLUSION}

Tin deposits abound in two major metallogenic provinces in Nigeria - the rare metal-bearing pegmatite and Younger Granite provinces. Minor occurrences of tin are found in mineralized pegmatites in the Obudu and Oban massifs of southeastern Nigeria. The total estimated tin (cassiterite and stannite) reserve of Nigeria is at least 300,000 tonnes. A substantial amount of the tin-bearing deposits, as revealed by geological (geochemical, mineralogical and geophysical) and economic studies, are minable at profit.

Tin ores occur in association with tantalite, niobite (columbite), sphalerite, gemstones and other economic minerals in the tin metallogenic provinces of Nigeria. This association makes mining of cassiterite profitable because other economic minerals can also be recovered in the process. New measures must be put in place to encourage tin mining in Nigeria as it is a viable source of revenue to the nation if properly exploited.

\section{REFERENCES}

[1] Umeshwar P. (2011). Economic Geology (Economic Mineral Deposits). 2nd ed. CBS Publishers and Distributors, p. 319.

[2] Kinnaird JA, Nex PAM, Milani L. (2016). Tin in Africa. $\quad$ Episodes 39(2): 361-380. https://doi.org/10.18814/epiiugs/2016/v39i2/95783

[3] New Age Exploration Ltd. (NAE Ltd.) (2016). Redmoor Resource Update.

[4] Evans AM. (1993). Ore Geology and Industrial Minerals: An Introduction. 3rd ed. Wiley \& Sons, 400.

[5] Sainsbury CL. (1969). Tin Resources of the World. US Geological Survey Bulletin 1301, p. 55.

[6] Olade MA. (1980). Geochemical characteristics of tinbearing and tin-barren granites, northern Nigeria. Economic Geology 75: 71-82. https://doi.org/10.213/gsecongeo.75.1.71

[7] Carlin JF. (2012). Tin: Statistics and Information. United States Geological Survey Mineral Commodity Summaries, pp. 170-171. 
[8] International Tin Research Institute Ltd. (ITRI Ltd.). (2016). Report on Global Tin Resources \& Reserves (Security of Long-term Tin Supply). 20.

[9] U.S. Geological Survey (2018). Mineral Commodity Summaries: Tin, pp. 172-173.

[10] Imeokparia EG. (2015). The Applied Geochemist and the Challenges of Georesource Evaluation for Sustainable Development and Environmental Management. Inaugural Lecture delivered at University of Benin, Benin City, Edo State, Nigeria.

[11] Oyawoye MO. (1964). The Geology of the Nigerian Basement Complex. J. Nig. Min. Geo. Metallur. Soc. 1(2): 87-103.

[12] Reyment RA. (1965). Aspects of the Geology of Nigeria. Ibadan University Press, p. 133.

[13] Rahaman MA. (1988). Recent Advances in the Study of the Basement Complex of Nigeria. In: Oluyide PO, Mbonu WC, Ogezi AEO, et al. (eds) Precambrian Geology of Nigeria. Geological Survey of Nigeria, Kaduna. 11-43.

[14] Turner DC. (1983). Upper Proterozoic Schist Belts in the Nigerian Sector of the Pan-African province of West Africa. Prec. Res. 21: 55-79. https://doi.org/10.1016/0301-9268(83)90005-0

[15] Woakes M, Rahaman MA, Ajibade AC. (1987). Some metallogenetic features of the Nigerian basement. Jour. Afr. Earth Sci. 6(5): 655-664. https://doi.org/10.1016/0899-5362(87)90004-2

[16] Dada SS. (2006). Proterozoic evolution of Nigeria. In: Oshin O. ed, The Basement Complex of Nigeria and its Mineral Resources (A Tribute to Prof. M.A.O. Rahaman). Akin Jinad \& Co. Ibadan. 29-44.

[17] Obaje NG. (2009). Geology and mineral resources of Nigeria. Lecture Notes in Earth Sciences 120. SpringerVerlag Berlin Heidelberg. p. 221. https://doi.org/10.1007/978-3-540-92685-6

[18] Orazulike MD. (2002). The solid mineral resources of Nigeria: Maximizing utilization for industrial and technological growth. Inaugural Lecture Delivered at Abubakar Tafawa Balewa University, Bauchi, Nigeria.

[19] Whiteman AJW. (1982). Nigeria: Its Petroleum Geology, Resources and Potential. Graham and Trotman, London.

[20] Habib M, Xie, C. (2012). Nigeria's inland basins: Investment opportunities and environment. J. Petrol. Gas Explor. Res. 2(11): 202-211.

[21] Ford SO. (1981). The economic mineral resources of the Benue Trough. Earth Evol. Sci. 1(2): 154-163.

[22] Offodile ME. (1989). A review of the geology of the Cretaceous of the Benue valley. In: Kogbe CA. ed. Geology of Nigeria, 2nd ed., 365-376.

[23] Akande SO. (2003). Minerals and fossil fuels discovery: The adventures of exploration. Inaugural Lecture delivered at University of Ilorin, Ilorin, Nigeria.

[24] Fatoye FB, Gideon YB. (2013). Geology and mineral resources of the Lower Benue trough, Nigeria. Advances in Applied Science Res. 4(6): 21-28.

[25] Okunlola OA. (2006). Regional metallogeny of rare metal $(\mathrm{Ta}-\mathrm{Nb})$ mineralization in Precambrian pegmatites of Nigeria. In: Oshin O. ed, The Basement Complex of Nigeria and its Mineral Resources (A Tribute to Prof. M.A.O. Rahaman). Akin Jinad \& Co. Ibadan, 107-126.

[26] Okunlola OA. (2017). Riches beneath our Feet: Mineral
Endowment and Sustainable Development of Nigeria. Inaugural Lecture delivered at University of Ibadan, 92.

[27] Woakes M. (1988). Basement Metallogeny of Northwestern Nigeria. In: Oluyide PO, Mbonu WC, Ogezi AEO, et al, (eds). Precambrian Geology of Nigeria. Geological Survey of Nigeria, Kaduna, Nigeria, 183-194.

[28] Garba I. (2003). Geochemical discrimination of newly discovered rare metal-bearing and barren pegmatites in the Pan-African $(600+150 \mathrm{Ma})$ Basement of Northern Nigeria. App. Earth Sci. Trans. Inst. Min. Metal. 13: 287-291.

[29] Okunlola OA. (2005). Metallogeny of $\mathrm{Ta}-\mathrm{Nb}$ mineralization of Precambrian pegmatites of Nigeria. Mineral Wealth 137: 38-50.

[30] Dada SS, Onema A, Rahaman A, Garba I. (2015). Lead reservoirs and metallization in Nigeria: Example of contrasting geological terrains. J. Geosci. Geomatics 3(2): 28-36. https://doi.org/10.12691/jgg-3-2-1

[31] Ogundipe IE, Obasi RA. (2016). Geology and mineralisation in the Albian Sediments of the Benue Trough, Nigeria. British J. Earth Sci. Res. 4(3): 1-15.

[32] Matheis G, Emofurieta WO. (1990). The Older Tin province rare-metal pegmatite in Nigeria. Technical University of Berlin (West) Special Research Project on Arid Areas and University of Ife, Nigeria, 10.

[33] Okunlola OA. (2008). Compositional trend in relation to $\mathrm{Ta}-\mathrm{Nb}$ mineralization in the Precambrian Pegmatite of Aramoko-Ijero area, southwestern Nigeria. J. Min. Geo. 42(2): 113-126.

[34] Morteani G, Preinfalk C, Horn AH. (2000). Classification and mineralization potential of the pegmatites of the Eastern Brazilian Pegmatite Province. Mineral. Deposita 35: 638-655.

[35] Beurlen H, da Silva MRR, Thomas R, Soares DR, Olivier P. (2008). Nb-Ta-(Ti-Sn) oxide mineral chemistry as tracer of Rare-Element Granitic Pegmatite fractionation in the Borborema Province, Northeastern Brazil. Mineral. Deposita 43: 207-228.

[36] Wright JB. (1970). Controls of mineralization in the older and younger tin fields of Nigeria. Econ. Geol. 51: 303-332.

[37] Ero KA, Ekwueme BN. (2009). Mineralization of pegmatites in parts of the Oban Massif, Southeastern Nigeria: A preliminary analysis. Chinese J. Geochem. 28(2): 146-153.

[38] Ministry of Mines and Steel Development (MMSD). (2012). Nigeria Mineral Projects. 36.

[39] Oden MI, Igonor EE, Ukwang EE. (2013). Geochemical evaluation of the Pan-African pegmatites from parts of Oban massif, southeast Nigeria. RMZ - M\&G. 60: 3946.

[40] Edem GO, Ekwueme BN, Ephraim BE. (2015). Geochemical signatures and mineralization potentials of Precambrian pegmatites of Southern Obudu, Bamenda Massif, Southeastern Nigeria. Inter. J. Geophy. Geochem. 2(3): 53-67.

[41] Matheis G. (1979). Geochemical exploration around the pegmatitic Sn-Nb-Ta Mineralization of Southwest Nigeria. Geol. Soc. Malaysia 11: 333-351.

[42] Akinbobola OO. (2016). Trace and rare earth elements geochemistry of pegmatites in Ijero area of Ekiti State, Southwestern Nigeria [Unpub. B.Sc. Dissertation]. Department of Geological Sciences, Achievers 
University, Owo, Nigeria, 42.

[43] Okunlola OA, Akinola OO. (2010). Petrochemical Characteristics of the Precambrian Rare Metal Pegmatite of Oke-Asa area, Southwestern Nigeria: Implication for $\mathrm{Ta}-\mathrm{Nb}$ mineralization. $\mathrm{RMZ}-$ Materials and Geoenvironment 57(4): 525-538.

[44] Agunleti YS, Arikawe EA, Okegye JIK. (2014). Geochemical Assessment of Tin-Tantalum Mineralization in the Precambrian Pegmatite Exposed at Angwan Rimi, Part of Sheet 208 NE, North Central Nigeria. Pacific J. Sci. Tech. 15(1): 415-425.

[45] Adekeye JID, Akintola OF. (2007). Geochemical features of rare metal pegmatites in Nassarawa Area, Central Nigeria. J. Min. Geo. 43(1): 15-21.

[46] Okunlola OA, Ocan OO. (2009). Rare Metal (Ta-Sn-LiBe) distribution in Precambrian Pegmatites of Keffi area, Central Nigeria. Nature and Sci. 7(7): 90-99.

[47] Abdullahi AM. (2011). Geology and Petrochemistry of Gwon-Gwon Pegmatite Field Wamba, Nasarawa State [Unpub. M.Sc. Dissertation]. Abubakar Tafawa Balewa Univ., Bauchi, 97.

[48] Okunlola OA, Udoudo OB. Petrochemical Characteristics and Age of Rare Metal (Ta-Nb) Mineralization in Precambrian Pegmatites, Komu, Nigeria. Int. Jour. Econ. \& Environ. Geol. 1(1): 21-26.

[49] Okunlola OA, Oyedokun MO. (2009). Compositional trends and rare metal $(\mathrm{Ta}-\mathrm{Nb})$ mineralization potential of pegmatite and association lithologies of Igbeti area, Southwestern Nigeria. J. RMZ-Materials and Geoenvironment 56(1): 38-53.

[50] Okunlola OA, Akintola AI. (2007). Geochemical Features and Rare Metal Ta-Nb Potentials of Precambrian Pegmatites of Sepeteri area, southwestern Nigeria. Ife J. Sci. 9(2): 203-214.

[51] Aderogbin JA, Okunlola OA. (2016). Compositional characteristics and rare metal $\mathrm{Ta}-\mathrm{Sn}-\mathrm{Nb}$ mineralization appraisal of pegmatite around Egbe area, central Nigeria. Book of Abstracts, Nigerian Mining and Geosciences Society Conference, Ilorin, Nigeria, 92.

[52] Oyebamiji AO. (2014). Petrography and Petrochemical characteristics of rare metal pegmatites around Oro, Southwestern Nigeria. Asia Pacific J. Energy and Environment 1(1): 70-88.

[53] Akintola AI, Omosanya KO, Ajibade OM, Okunlola OA, Kehinde-Philips OO. (2011). Petrographic and geochemical evaluations of Rare-Metal (Ta-Nb) potentials of Precambrian pegmatites of Awo Area, Southwestern Nigeria. Inter. J. Basic \& App. Sci. 11(4): 57-70.

[54] Matheis G. (1987). Nigerian rare metal pegmatites and their lithological framework. J. Geol. 22: 271-291. https://doi.org/10.1002/gj.3350220620.

[55] Matheis G, Caen-Vachette M. (1988). Rb-Sr Isotopic study of Rare Metal-bearing and barren pegmatites in the Reactivation Zone of Nigeria. In: Oluyide PO, Mbonu WC, Ogezi AEO, et al, eds. Precambrian Geology of Nigeria. Geological Survey of Nigeria, Kaduna, 291-299.

[56] Wright JB. (1981). Review of the origin and evolution of the Benue Trough in Nigeria. Earth Evol. Sci. 1(2): 98-100.

[57] Imeokparia EG. (1988). Mesozoic granite magmatism and tin mineralization in Nigeria. In: Taylor RP, Strong DF. (eds.) Recent Advances in the Geology of Granite- related Mineral Deposits. Canadian Instit. Mining and Metallurgy Special 39: 133-141.

[58] Jacobson RR, MacLeod WN, Black R. (1958). Ring complexes in the Younger Granites of northern Nigeria. Geol. Soc. London Memoir 1: 5-9.

[59] Kinnaird JA. (1981). Geology of the Nigerian Anorogenic Ring Complexes 1: 500,000 Geological Map. John Bartholomew and Sons.

[60] Ekwere SJ. (1985). Li, F and $\mathrm{Rb}$ contents and $\mathrm{Ba} / \mathrm{Rb}$ and $\mathrm{Rb} / \mathrm{Sr}$ ratios as indicators of postmagmatic alteration and mineralization in the granitic rocks of the Banke and Ririwai Younger Granite complexes, Northern Nigeria. Mineral. Deposita 20: 89-93.

[61] Imeokparia EG. (1992) Geochemical and Isotopic evidence for crystal melt + fluid phase equilibria and late stage fluid rock interaction in granitic rocks of the Ririwai Complex, Northern Nigeria. African Jour. of Sci. and Tech. 6(2): 24-35.

[62] Imeokparia EG. (1983). Lithogeochemical dispersion associated with Ririwai zinc-tin lode, northern Nigeria. In: Parslow GR ed, Geochem. Explor. 19: 643-661.

[63] Kinnaird JA. (1985). Hydrothermal alteration and mineralization of the Alkaline Anorogenic ring complexes of Nigeria. J. Afr. Earth Sci. 3(2): 229-251.

[64] Imeokparia EG. (1985). Rare-metal Mineralization in Granitic rocks of Tongolo Anorogenic Complex, Northern Nigeria. Mineral Deposita 20: 81-88.

[65] Imeokparia EG. (1981). $\mathrm{Ba} / \mathrm{Rb}$ and $\mathrm{Rb} / \mathrm{Sr}$ ratios as indicators of magmatic fractionation, postmagmatic alteration and mineralization - Afu Younger Granite Complex, Northern Nigeria. Geochem. J. 15: 209-219.

[66] Imeokparia EG. (1990). The shere igneous Complex, central Nigeria: geochemical constraints on the origin of peralkaline and associated granites. Geologic en Mujinbow 69(2): 121-131.

[67] Imeokparia EG. (1984). Geochemistry of Granitic rocks from the Kwandonkaya Complex, Northern Nigeria. Lithos 17: 103-115.

[68] Ogunleye PO, Ike EC, Garba I. (2004). Multivariate statistical analysis of major and trace element data for niobium exploration in the Peralkaline Granites of the Anorogenic Ring-Complex Province of Nigeria. Jour. Min. Geol. 40(2): 107-117.

[69] Kogbe CA. (1989). Statistics of Mineral Production in Nigeria (1968 to 1986) and the Contribution of the Mineral Industry to the Nigerian Economy. In: Kogbe CA. ed. Geology of Nigeria, 2nd ed, 485-529.

[70] Ajibade AC, Wright JB. (1989). The Togo-BeninNigeria Shield: Evidence of Crustal Aggregation in the Pan-African Belt. Tectonophysics 165: 125-129.

[71] Okunlola OA. (2011). Precambrian Ta-Nb (Coltan) Pegmatites of Nigeria: Distribution, Petrogenetic Features and Economic Potentials. Book of Abstracts, Nigerian Mining and Geosciences Society Conference, Minna, pp. 11.

[72] Garba I. (2002). Late Pan-African tectonics and origin of gold mineralization and rare-metal pegmatites in the Kushaka Schist Belt, Northwestern Nigeria. Nig. Journal of Mining and Geology 38: 1-12. https://doi.org/10.4314/jmg.v38i1.18768

[73] Gyang JD, Nanle N, Chollom SG. (2010). An overview of mineral resources development in Nigeria: Problems and prospects. Continental Jour. Sust. Dev. 1: 23-31. 
[74] Kampunzu AB, Lubala RT. (1991). Magmatism in extensional structural settings - the Phanerozoic African plate. Springer-Verlag Berlin Heidelberg, 637.
[75] Malomo S. (2007). Nigeria mineral resources. Paper presented at the International Workshop on Sustainable Development of Nigeria's Mineral Potentials.

[76] U. S. Bureau of Mines (1966). Mineral Trade Notes 63(5): 51 . 